\title{
Improving Students' Preparedness toward Earthquake Disasters through Multimedia at SMAN 1 Meulaboh
}

\author{
Desi Jumaidir\& Teuku Budi Aulia \\ Disaster Science Postgraduate Program, Syiah Kuala University, Banda Aceh, Indonesia
}

http://dx.doi.org/10.18415/ijmmu.v6i2.854

\begin{abstract}
This study aim to explore students' preparedness at SMAN 1 Meulaboh in facing earthquake disasters through multimedia. This study applied a quantitative approach with a confirmatory method. This research took place at senior High School 1 Meulaboh while the population was 127 students representing of X class, XI class, XII class for all majors. The data collected through the questionnaire method obtained from students and it was carried out in two phases; pre-test instrument and post-test instrument in graph form. The analyze data used SPSS (Statistical Product Service Solutions) software. The results showed that (1) SMAN 1 Meulaboh is a high category school of preparedness score. (2) The students' knowledge, attitudes, feelings, actions, and responsibilities, levels of difficulty, generality, and strength increased. Therefore, this study confirmed that the students' preparedness improved in facing earthquake disasters after learning (post test) than before learning (pre test), especially in school.
\end{abstract}

Keywords: Multimedia; Preparedness; Earthquakes

\section{Introduction}

Law number 24 of 2007 states that a disaster is an event or series of events that threatens and disrupts people's lives caused by natural factors and / or non-natural factors and human factors resulting in human casualties, environmental damage, property losses and impacts psychological. Then in article 1 point 7 explained preparedness is a series of activities carried out to anticipate disasters through organizing and through appropriate and efficient steps.

The December 26, 2004 earthquake and tsunami disaster in Aceh with the record of death and disappearance was 265,896 people (BRR, 2009) and experience in tackling disasters has contributed to improving preparedness. Geographically, West Aceh Regency is often hit by earthquake disasters, such as the events on Thursday, October 18, 2018 at 11:19 a.m. WIB, 5.3 magnitude, $10 \mathrm{~km}$ depth, $30 \mathrm{~km}$ northeast, The earthquake center is located at the coordinates of 960.21 'BT and 4,702' LU, (Serambi Indonesia, 2018). In reducing disaster risk, it is necessary to establish a school community to improve preparedness in anticipating and reacting quickly and appropriately to disasters needing cognitive management strategies, affective management, and psychomotor training (Ayriza, 2009).

The Hyogo Framework for Action / HFA Framework (2005-2015), disaster preparedness education is a priority in reducing disaster risk, for local, national, regional and global levels. This is 
stated in Priority for Action 3 namely use knowledge, innovation and education to build a culture of safety and resilience at all levels. The replacement document for the framework of the Sendai Framework for Disaster Risk Reduction/ SFDRR (2015-2030) also continue to emphasize the importance of preparedness education, as stated in Priority for Action 4: enhancing disaster preparedness for effective response, and to " Build Back Better " in recovery, rehabilitation, and reconstruction (UNISDR, 2015).

The government has committed to supporting disaster risk reduction in schools through policies, one of which is a circular letter from the Minister of National Education No.70a / MPN / SE / 2010 issued on July 29, 2010 concerning mainstreaming disaster risk reduction in schools. Students of SMAN 1 Meulaboh must be familiar with the state of the school environment, if an earthquake occurs suddenly it can save itself to a safer place, so it can reduce casualties. Students also need to increase their awareness to continue to learn the importance of preparedness, because one of the efforts is to reduce casualties.

The use of multimedia as a learning aid is a combination of text, art, sound, animation, and video delivered through computers or electronic and digital equipment (Vaughan, 2006). Then it will be able to provide clear meaning to people who need it. The word multimedia is used to describe a system consist of hardware, software, and equipment such as a television, monitor, disk or display system used for the purpose of presenting videos or presentations.

Based on the description above, the researchers examinedstudent preparedness in facing earthquake disasters, while the aim of this study was to find out how much influence was driven by multimedia use on improving preparedness in the school environment. Thus, the researchers come up with the issue "Improving student preparedness for earthquake disasters through multimedia at SMAN 1 Meulaboh".

\section{Research Design, Data Collection Instrument and Material Studied}

\subsection{Research Design}

Appropriate research design and use in this study was a quantitative approach with a confirmative method. The researchers assumed that this method has met scientific principles, namely concrete / empirical, objective, measurable, rational, and systematic. All symptoms observed and measured in the form of numbers and analysis using statistics. Thus quantitative methods can be interpreted as research methods that are based on the philosophy of positivism, used to examine certain populations or samples, data collection using research instruments, quantitative / statistical data analysis, with the aim to test the predetermined hypothesis (Sugiyono, 2018).

Table 1 Students representing research to improve preparedness for earthquakes through multimedia

\begin{tabular}{|c|l|c|c|}
\hline No & Description & Department & $\begin{array}{c}\text { The Numbers } \\
\text { of students }\end{array}$ \\
\hline 1 & Students X & IPS & 21 \\
\hline 2 & Students X & IPA & 21 \\
\hline 3 & Students XI & IPS & 21 \\
\hline 4 & Students XI & IPA & 21 \\
\hline 5 & Students XII & IPS & 22 \\
\hline 6 & Students XII & IPA & 127 \\
\hline
\end{tabular}

Source: SMAN 1 Meulaboh (2019) 


\subsection{Data Collection Instrument}

The data collection instrument used in this study used a questionnaire, which was carried out in two stages, namely before learning (pre test) and after learning (post test) in the form of graphs and statistics, with the aim of measuring multimedia use with student preparedness for earthquake disasters. The multimedia used in the learning phase is as follows:

- The school-based disaster risk reduction program comic related to the earthquake (YTB-OCHA, 2008) lasts about 10 minutes

- The earthquake disaster cartoon animation (BNPB, 2013) has a duration of 7 minutes 23 seconds

- The documentary video for learning about earthquake disaster material (BNPB, 2005) has a duration of 19 minutes 30 seconds.

Questionnaires are given to students, which are related to the use of multimedia by increasing student preparedness designed in a language that is easily understood by students. Questionnaires are filled out by students based on answers for each statement adjusted to the answer column available on the questionnaire.

\subsection{Variable Measurement}

\subsubsection{Variable Measurement}

Preparedness of students in dealing with earthquake disasters is the ability to anticipate disasters with indicators of knowledge, attitudes, feelings, actions, responsibilities. The attachment questionnaire consists of 50 statements that represent each of the indicators in preparedness.

\subsubsection{Multimedia Variable}

The use of multimedia can increase the effectiveness of delivering information, especially about earthquake natural disasters. Multimedia applications can stimulate the five senses, because the use of multimedia will stimulate some important human senses, such as: vision, hearing, action and sound with several indicators including the level of difficulty, generality, and strength. The attachment questionnaire consists of 30 statements that represent each dimension in multimedia usage.

\subsubsection{Test Questionnaire Validity and Reliability}

In conducting data collection, researchers prepared a questionnaire, after the preliminary survey conducted.. The purpose was to find out the validity and reality of the questionnaire on the use of multimedia and preparedness. The two questionnaires will be analyzed using SPSS software (Statistical Product Service Solutions).

Table 2 High, medium and low category counts

\begin{tabular}{|c|c|c|}
\hline Category & Formu.la & Percentage \\
\hline High & $\mathrm{X}>(\mu+1 . \sigma)$ & $\mathrm{X}>36,65$ \\
\hline Medium & $(\mu-1 . \sigma)<\mathrm{X}<(\mu+1 . \sigma)$ & $23,35<\mathrm{X}<36,65$ \\
\hline Low & $\mathrm{X}>(\mu-1 . \sigma)$ & $\mathrm{X}<23,35$ \\
\hline
\end{tabular}




\section{Research Results and Study}

\subsection{Research Result}

This study involved 127 students randomly selected with the principle of balance between men and women and all representing classes in SMAN 1 Meulaboh as many as 20 (twenty) teaching and learning spaces, they were given a questionnaire to be filled with the first stage, namely pre test especially first as a guideline for the initial value to what extent students know about preparedness when earthquakes occur, after that the teaching and learning process was carried out with the material related to the earthquake and then the final stages of the post test were carried out again to distribute the questionnaire which was the same as the pre test questions aimed at testing and evaluating the initial results before learning was carried out.

Table 3 Percentage difference from earthquake natural disaster preparedness questionnaire

\begin{tabular}{|c|c|c|c|c|c|c|c|c|c|}
\hline \multicolumn{2}{|c|}{ School } & \multicolumn{8}{|c|}{ Faktor yang mempengaruhi } \\
\hline & & Knowledge & Attitude & Feeling & Action & Responsibility & $\begin{array}{l}\text { The level } \\
\text { of } \\
\text { difficulty }\end{array}$ & Generality & Strengtg \\
\hline \multirow{3}{*}{ 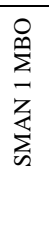 } & Pre & $61,00 \%$ & $60,65 \%$ & $61,06 \%$ & $60,98 \%$ & $60,93 \%$ & $61,36 \%$ & $61,06 \%$ & $60,53 \%$ \\
\hline & Post & $92,68 \%$ & $92,34 \%$ & $92,72 \%$ & $92,62 \%$ & $92,32 \%$ & $92,09 \%$ & $92,56 \%$ & $91,59 \%$ \\
\hline & Gap & $31,68 \%$ & $31,69 \%$ & $31,66 \%$ & $31,64 \%$ & $31,39 \%$ & $30,73 \%$ & $31,50 \%$ & $31,06 \%$ \\
\hline
\end{tabular}

Percentage of pre and posttest quesionare onearthquake natural disaster preparedness

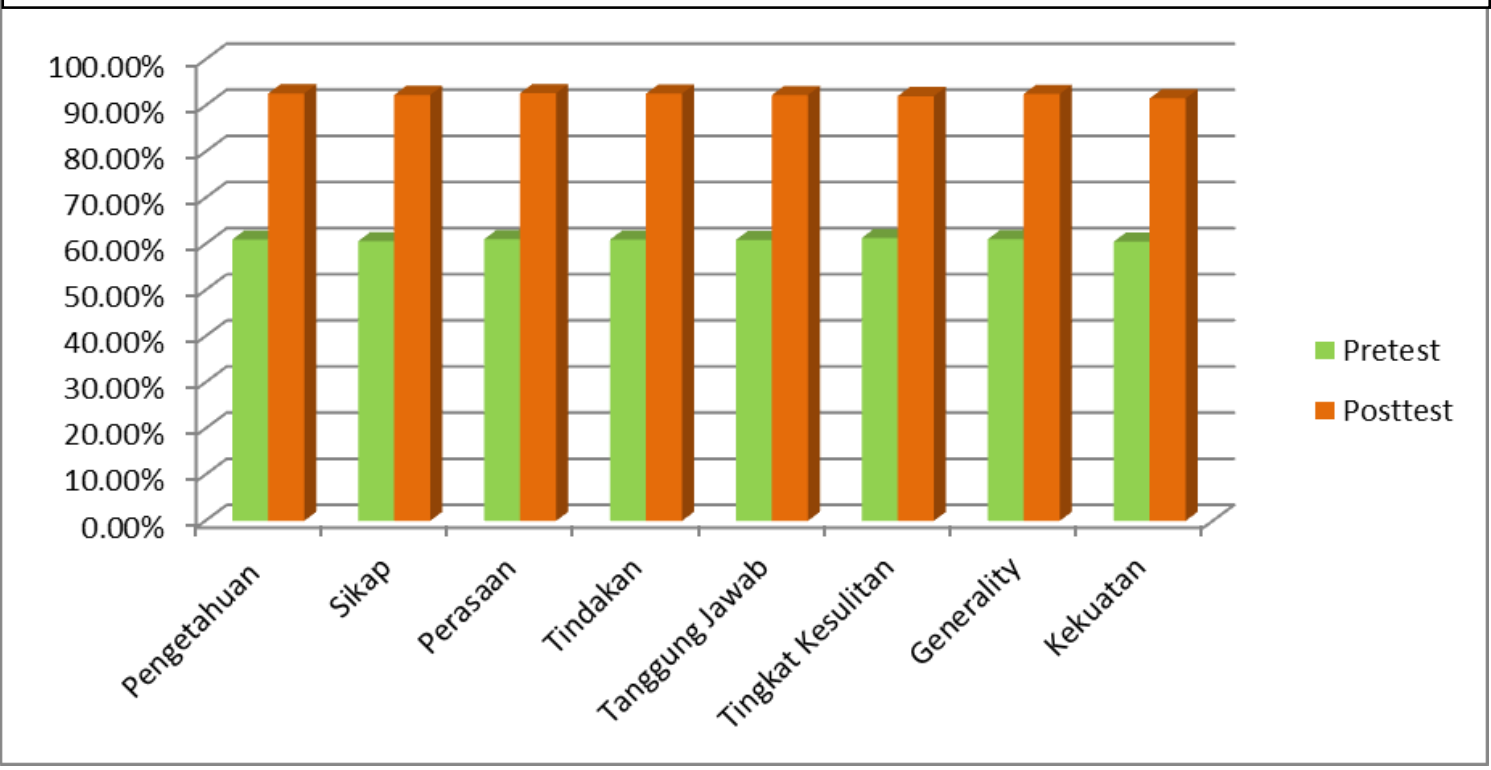

Tabel 4. Percentage of earthquake disaster preparedness questionnaire in pre-posttest 


\subsubsection{Students' Knowledge in Facing Earthquake Disasters}

In this aspect consists of 10 statements relating to knowledge of earthquake disasters (according to attached), from the results of these answers can be known student knowledge, that all respondents are representing students of SMAN 1 Meulaboh, give a very agreeable answer in the statement for the knowledge aspect at the pre test stage with a percentage of $61.00 \%$ while at the post test stage the percentage is $92.68 \%$. From the answer to the difference in percentage, there is an increase in students' knowledge about earthquakes.

\subsubsection{Attitude of Student's in Facing Earthquake Disasters}

This aspect consists of 10 statements regarding attitudes towards earthquake disasters (as attached). From the results of these answers, it can be seen the attitude of students, it can be seen that all respondents represented by 127 students of SMAN 1 Meulaboh gave answers to attitude aspects at the pre-test stage with a percentage of $60.65 \%$ while at the post-test stage the percentage was $92.34 \%$. From the answer to the difference in percentage, there is an increase in the field of student attitudes towards earthquakes. Students can show awareness of increasing their preparedness for earthquake disasters and student attitudes are still very minimal in the pre test, while after the learning process through multimedia students increasingly understand in improving attitudes about earthquakes.

\subsubsection{Feeling of Student's in Facing Earthquake Disasters}

This aspect consists of 10 statements relating to feelings about earthquake disasters (as attached). From the results of these answers can be seen the feelings of students, that all respondents represented 127 students of SMAN 1 Meulaboh gave answers to aspects of feeling at the pre-test stage with a percentage of $61.06 \%$ while at the post-test stage the percentage was $92.72 \%$. From the answer to the difference in percentage, there is an increase in the field of students' feelings towards earthquakes. Students can show feelings in improving their preparedness for earthquake disasters and students' feelings are still very minimal in the pre test, while after the learning process through multimedia students increasingly understand in increasing their feelings about earthquakes.

\subsubsection{Action of Student's in Facing Earthquake Disasters}

This aspect consists of 10 statements concerning actions against earthquake disasters (as attached). From the results of these answers can be seen the actions of students, that all respondents represented 127 students of SMAN 1 Meulaboh gave answers to aspects of the action at the pre-test stage with a percentage of $60.98 \%$ while at the post-test stage the percentage was $92.62 \%$. From the answer to the difference in percentage, there is an increase in the field of student action against earthquakes. Students can show actions in increasing their preparedness for earthquake disasters and student actions are still very minimal in the pre test, while after the learning process through multimedia students increasingly understand in increasing actions against earthquake natural disasters.

\subsubsection{Responsibilities of Student's in Facing Earthquake Disasters}

This aspect consists of 10 statements relating to responsibility for earthquake disasters (as attached). From the results of these answers, it can be seen the student's responsibility, that all respondents represented by 127 students of SMAN 1 Meulaboh gave answers to aspects of responsibility at the pre test stage with a percentage of $60.93 \%$ while at the post test stage the percentage was $92.32 \%$. From the answers to the difference in percentage, there is an increase in the field of student responsibility for earthquakes. Students can show responsibility in increasing their preparedness for earthquake disasters and student responsibility is still very minimal in the pre test, while after the learning process through multimedia students increasingly understand in increasing responsibility for earthquake natural disasters.

The Effect of Organization Culture, Head Master's Entrepreneurial Competence, and Organization Climate on the Quality of Education Services of

Islamic Junior High Schools at Islamic Boarding Schools in Praya, Central Lombok 


\subsubsection{Level of Difficulties of Student's in Facing Earthquake Disasters}

This aspect consists of 10 statements relating to the level of difficulty of earthquake disasters (as attached). From the results of these answers can be seen the level of difficulty of students, that all respondents represented 127 students of SMAN 1 Meulaboh gave answers to aspects of the level of difficulty in the pre-test stage with a percentage of $61.36 \%$ while at the post-test stage the percentage was 92.09\%. From the answer to the difference in percentage, there is an increase in the field of students' difficulty level against earthquakes. Students can show the level of difficulty in improving their preparedness for earthquake disasters and the level of difficulty of students is still very minimal in the pre test, while after the learning process through multimedia students increasingly understand in increasing the level of difficulty of earthquake natural disasters.

\subsubsection{Generality of Student's in Facing Earthquake Disasters}

This aspect consists of 10 statements relating to the generality of earthquake disasters (as attached). From the results of the answers it can be seen the generality of the students, that all respondents represented by 127 students of SMAN 1 Meulaboh gave answers to the generality aspects in the pre test stage with a percentage of $61.06 \%$ while the post test stage the percentage was $92.56 \%$. From the answer to the difference in percentage, there is an increase in the generality of the students towards the earthquake. Students can show generality in improving their preparedness for earthquake disasters and the generality of students is still very minimal in the pre test, while after the learning process through multimedia students increasingly understand in increasing generality of earthquake natural disasters.

\subsubsection{Strength of Student's in Facing Earthquake Disasters}

This aspect consists of 10 statements relating to the strength of earthquake disasters (as attached). From the results of these answers it can be seen the strength of students, that's all respondents from the represented 127 students of SMAN 1 Meulaboh gave answers to aspects of strength at the pre-test stage with a percentage of $60.53 \%$ while at the post-test stage the percentage was $91.59 \%$. From the answer to the difference in percentage, there is an increase in the field of student strength towards the earthquake. Students can show strength in increasing their preparedness for earthquake disasters and students' strength is still very minimal in the pre test, while after the learning process through multimedia students increasingly understand in increasing the strength of earthquake natural disasters.

\section{Conclusions}

From the results of the research and discussion that has been described, then conclusions can be made to increase student preparedness for earthquake disasters through multimedia at SMAN 1 Meulaboh as follows:

1) The existence of strategies and methods of geography teachers through multimedia in the teaching and learning process about earthquake natural disasters to improve student preparedness at SMAN 1 Meulaboh.

2) The score category of student preparedness against to earthquake through multimedia was categorized as high, this showed that there was a percentage increase in all aspects tested.

3) Students of SMAN 1 Meulaboh after getting exposure to the material about earthquake natural disasters, when viewed from the results of the pre-test students were very low in percentage but after teaching and learning process was carried out there was an increase in the percentage so we concluded all students who followed this research they have been able to understand what they must 
be done when an earthquake occurs and students have the ability to convey earthquake material to other students who have not been directly involved in this research.

\section{References}

Ayriza, Y. (2009). Pengembangan Modul Bimbingan Pribadi Sosial Bagi Guru Bimbingan Konseling Untuk Menghadapi Bencana Alam. Jurnal Kependidikan Volume 39, Nomor 2. November 2018. Hal 141-156.

BRR. (2009). Tsunami: Habis Bencana Terbitlah Terang. Badan Pelaksana Rehabilitasi dan Rekontruksi Nanggroe Aceh Darussalam dan Kepulauan Nias.

Pemerintah Republik Indonesia. (2007). Undang-Undang RI Nomor 24 Tahun 2007 tentang Penanggulangan Bencana. Jakarta.

Sugiyono. (2018). Metode Penelitian Kombinasi (Mixed Methods). Bandung: Alfabeta.

Surat Edaran Menteri Pendidikan Nasional No. 70a/MPN/SE/2010 tentang Pengarusutamaan Pengurangan Risiko Bencana di Sekolah.

UNISDR. (2015). Sendai framework for disaster risk reduction 2015-2030. United Nations International Strategy for Disaster Reduction.

Vaughan, Tay. (2006). Multimedia:Making It Work,Edisi 6. Yogyakarta : ANDI.

\section{Copyrights}

Copyright for this article is retained by the author(s), with first publication rights granted to the journal.

This is an open-access article distributed under the terms and conditions of the Creative Commons Attribution license (http://creativecommons.org/licenses/by/4.0/). 